\title{
NON-SYMBIOTIC NITROGEN FIXATION, NET NITROGEN MINERALIZATION AND DENITRIFICATION IN EVERGREEN FORESTS OF CHILOÉ ISLAND, CHILE: A COMPARISON WITH OTHER TEMPERATE FORESTS
}

\author{
FIJACION NO-SIMBIOTICA, MINERALIZACION NETA DEL NITROGENO Y \\ DESNITRIFICACION EN BOSQUES SIEMPREVERDES DE CHILOE, CHILE: \\ UNA COMPARACION CON OTROS BOSQUES TEMPLADOS
}

\author{
C.A. Pérez ${ }^{1}$, M.R. Carmona² \& J.J. Armesto ${ }^{1,2}$
}

\begin{abstract}
Temperate forests in southern Chile offer unique opportunities for studying biogeochemical cycles in the absence of industrial air pollution. Here we compare three important fluxes of the nitrogen $(\mathrm{N})$ cycle in temperate forests of southern Chile, non-symbiotic $\mathrm{N}$ fixation, net $\mathrm{N}$ mineralization and denitrification, with data from northern temperate forests more affected by air pollution. We studied five evergreen, old-growth forests and one second-growth forest in Chiloé Island, southern Chile. Non-symbiotic $\mathrm{N}$ fixation in the litter layer, mineral soil and coarse woody debris was estimated by the acetylene reduction technique. In situ net-N mineralization in the upper mineral soil layer was assessed by the buried bag method. Denitrification rates of mineral soil were assessed by the acetylene inhibition essay in intact soil cores. Results show that in some southern temperate forests a greater proportion of the ecosystem $\mathrm{N}$-fixation occurs in the litter layer $\left(0.23-2.26 \mathrm{~kg} \mathrm{~N} \mathrm{ha}^{-1}\right.$ year-1 $\left.^{-1}\right)$ and coarse woody debris (1.31-1.34 kg N ha-1 year $\left.^{-1}\right)$. In contrast, the highest $\mathrm{N}$ fixation rates in northern temperate forests occur in mineral soil. Rates of both $\mathrm{N}$ mineralization and denitrification were considerably lower in Chiloé forests than in northern temperate forests, which are subject to higher $\mathrm{N}$ deposition. These findings suggest that southern temperate forests exert a stronger biotic control on $\mathrm{N}$ cycling than their northern counterparts.
\end{abstract}

Keywords: Denitrification, nitrogen cycle, nitrogen fixation, temperate forests, unpolluted forests.

${ }^{1}$ Center for Advanced Studies in Ecology \& Biodiversity, Pontificia Universidad Católica de Chile, Santiago, Chile. Address for correspondence C. Pérez: Universidad Católica de Chile, Departamento de Ecología, Casilla 114-D, Santiago, Chile. E-mail: cperez@uchile.cl

${ }^{2}$ Lab. Sistemática \& Ecología Vegetal, Universidad de Chile, Facultad de Ciencias, Santiago, Chile.

\section{RESUMEN}

Los bosques templados de Chile ofrecen un escenario único para estudiar los ciclos biogeoquímicos debido a su condición libre de contaminación industrial. Comparamos tres flujos importantes del ciclo del nitrógeno $(\mathrm{N})$, tales como fijación no simbiótica, mineralización neta y desnitrificación, en bosques del sur de Chile con datos de bosques templados del hemisferio norte sujetos a contaminación. Estudiamos cinco bosques siempreverdes maduros y uno secundario en la Isla de Chiloé. La fijación no simbiótica del nitrógeno en la hojarasca, el suelo mineral y desechos leñosos gruesos, se estimó mediante el método de reducción de acetileno. La tasa neta de mineralización del suelo superficial se estimó con el método de la bolsa enterrada. La tasa de desnitrificación se estimó mediante el ensayo de inhibición con acetileno en muestras de suelo intactas. Los resultados muestran que en algunos bosques templados chilenos una mayor proporción de la fijación no simbiótica del $\mathrm{N}$ ocurre en la hojarasca $\left(0,23-2,26 \mathrm{~kg} \mathrm{~N} \mathrm{ha}^{-1} \mathrm{año}^{-1}\right)$ y en los desechos leñosos gruesos $\left(1,31-1,34 \mathrm{~kg} \mathrm{~N} \mathrm{ha}^{-1} \mathrm{año}^{-1}\right)$. En cambio, las mayores tasas de fijación de $\mathrm{N}$ en los bosques templados del hemisferio norte han sido encontradas en el suelo mineral. Los bosques siempreverdes de Chiloé presentaron tasas de mineralización neta y desnitrificación considerablemente menores que los bosques templados del hemisferio norte, tanto siempreverdes como deciduos. Interpretamos estos resultados como indicadores que los bosques templados del hemisferio sur poseen un control más eficiente de la circulación interna del $\mathrm{N}$ que su contra parte del hemisferio norte.

Palabras claves: Bosques no-contaminados, bosques templados, ciclo del N, desnitrificación, fijación de nitrógeno. 
Gayana Bot. 60(1), 2003

\section{INTRODUCTION}

During the last decade, the study of biogeochemical cycles in unpolluted, temperate forests of southern Chile has become especially relevant since the discovery of a peculiar pattern of nitrogen $(\mathrm{N})$ cycling, which contrasts with biogeochemical patterns described for northern hemisphere temperate forests. Southern temperate forests are characterized by the dominance of dissolved organic nitrogen (DON) in both atmospheric inputs and hydrological outputs (Weathers et al. 2000, Hedin et al. 1995, Perakis \& Hedin 2002). Such pattern differs markedly from most northern temperate forests in industrialized regions of the world, where both inputs and outputs are strongly dominated by dissolved inorganic nitrogen (Bormann \& Likens 1979, Johnson 1992). High inorganic N loads, due to industrial air pollution, may cause important alterations in ecosystem functioning, such as eutrofication of streams and lakes, soil acidification, and the loss of oligotrophic plant species, which are replaced by invasive species with high $\mathrm{N}$ requirements (Vitousek et al. 1997).

In unpolluted ecosystems were wet deposition is minimun for nitrate and ammonium, there are two major sources of $\mathrm{N}$ for organisms: non-symbiotic $\mathrm{N}$ fixation and the recycling of organic matter via litterfall to the forest floor, where it is decomposed by soil organisms (Fig. 1). The more labile fraction of soil organic matter (SOM) is then mineralized by soil microorganisms to ammonium and nitrate, both of which can be absorbed by plants and/or microbes (Fig. 1). Inorganic nitrogen in excess of ecosystem requirements may be lost via denitrification (a process by which certain soil microbes reduce nitrate to nitrous oxide $\left(\mathrm{N}_{2} \mathrm{O}\right.$ ) and $\mathrm{N}_{2}$ ), or leached to streamwater (Fig. 1). Dissolved organic nitrogen (DON) belongs to the non-mineralized fraction of SOM, composed primarily by fulvic and humic acids, aminoacids and urea. This is the dominant form of $\mathrm{N}$ in oldgrowth, temperate forests of southern South America and accounts for up to $95 \%$ of total dissolved $\mathrm{N}$ in stream water, versus $c a .8 \%$ in streams draining forested watersheds of the northern hemisphere (Hedin et al. 1995, Perakis \& Hedin 2002). As a consequence, northern temperate forests under chronic $\mathrm{N}$ deposition due to industrial pollution, tend to loose their ability to retain soil nitrate, and accumulate a lower proportion of DON. The reason for such changes in the biogeochemical patterns of $\mathrm{N}$ cycling remains unclear. Understanding $\mathrm{N}$ cycling in unpolluted old-growth, southern temperate forests is therefore of fundamental importance in understanding the consequences of global change, particularly the long-term effects of increasing $\mathrm{N}$ loads in forests and streams.

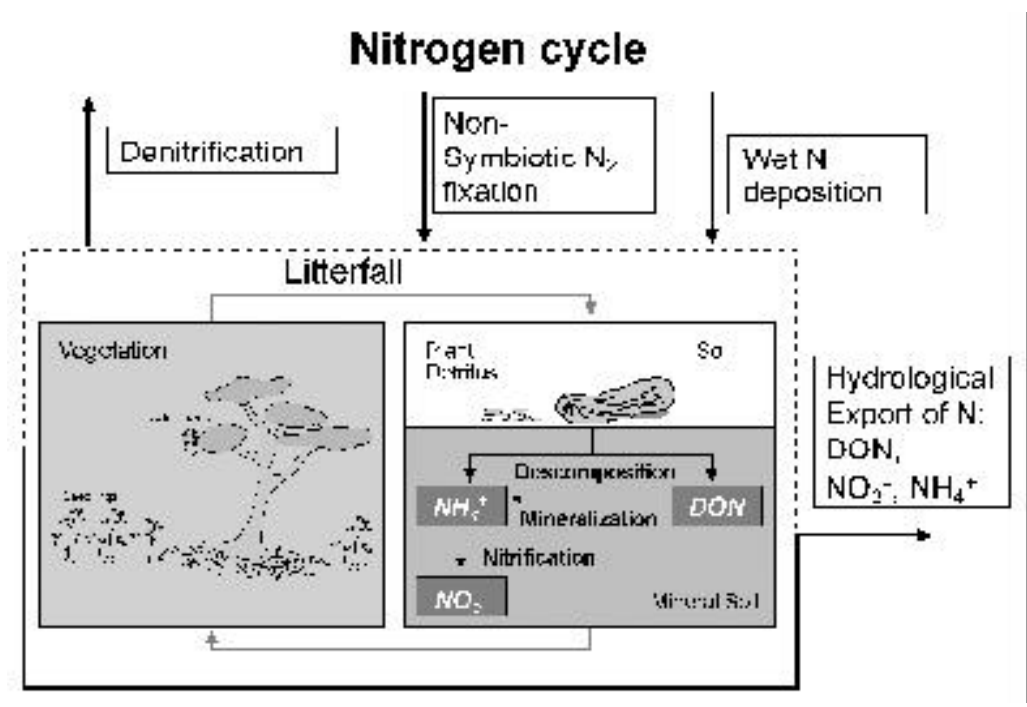

FIgURE 1. Major fluxes of the $\mathrm{N}$ cycle in a forest ecosystem. 
In this study we discuss how three critical microbial processes within the $\mathrm{N}$ cycle of southern temperate forests, non-symbiotic $\mathrm{N}$ fixation, net $\mathrm{N}$ mineralization and denitrification, compare with similar $\mathrm{N}$ fluxes in temperate forests of the northern hemisphere, which are subjected to high $\mathrm{N}$ loads as a consequence of industrial air pollution. High soil $\mathrm{N}$ availability is known to inhibit $\mathrm{N}$ fixation (Zuberer 1998), therefore higher rates of non-symbiotic $\mathrm{N}$ fixation are expected in unpolluted southern temperate forests than in northern temperate forests, because nitrate inputs through precipitation and cloudwater are higher in the latter. On the other hand, lower atmospheric $\mathrm{N}$ inputs to Chilean forest ecosystems should result in lower net mineralization and denitrification rates than in northern temperate forests.

TABLE I. Stand and soil characteristics of minimun study sites in Chiloé Island, Chile.

\begin{tabular}{|c|c|c|c|c|c|}
\hline Forest type* & Altitude & Stand Age (years) & Basal area $\left(\mathrm{m}^{2} \mathrm{ha}^{-1}\right)$ & Soil C/N & Soil pH \\
\hline $\begin{array}{l}\text { Nothofagus-Drimys- } \\
\text { Podocarpus }\end{array}$ & Lowland & 62 & 49.7 & 28 & 4.3 \\
\hline Nothofagus- Tepualia & Lowland & 129 & 58.6 & 32 & 4.2 \\
\hline $\begin{array}{l}\text { Nothofagus- Drimys- } \\
\text { Podocarpus }\end{array}$ & Lowland & 133 & 65.5 & 22 & 4.4 \\
\hline $\begin{array}{l}\text { Nothofagus-Drimys } \\
\text { Podocarpus }\end{array}$ & Lowland & 134 & 85.7 & 27 & 4.4 \\
\hline $\begin{array}{l}\text { Nothofagus-Drimys- } \\
\quad \text { Podocarpus }\end{array}$ & Montane & 300 & 87 & 33 & 4.6 \\
\hline $\begin{array}{c}\text { Fitzroya } \\
\text { Pilgerodendron }\end{array}$ & Montane & 400 & 69.5 & 39 & 4.3 \\
\hline
\end{tabular}

* Species names: Nothofagus nitida, Podocarpus nubigena, Drimys winteri, Tepualia stipularis, Fitzroya cupressoides, Pilgerodendron uviferum

\section{MATERIALS AND METHODS}

STUDY AREA

Data were collected from three lowland and two montane old-growth forests, as well as one secondary lowland forest located in Chiloé Island southern Chile (Table I). Lowland temperate rain forests in southern Chile have undergone extensive reduction in cover, due to disturbance by fire and logging. The present landscape is comprised by a mosaic of fragmented second-growth forests of different ages, within a matrix of pastures, cropfields and wetlands (Wilson \& Armesto 1996, Aravena et al. 2002). The montane temperate forests studied were located at $600 \mathrm{~m}$ elevation in National Park Chiloé (Pérez et al. 1998). These forests belong to the North Patagonian rainforest type (Armesto et al. 1995), characterized by a mixed canopy of evergreen species, including broad-leaved angiosperms (Nothofagus nitida (Phil.) Krasser, Drimys winteri J.R. et G. Forster) and narrowleaved conifers (Podocarpus nubigena Lindl.) (Table I). In poorly drained areas, the canopy may be dominated by Tepualia stipularis (H. et A.) Griseb and Nothofagus nitida (Table I).

In each lowland forest we set up a $20 \times 50 \mathrm{~m}$ permanent plot for sampling stand structure. For soil sampling, two parallel transects were run along the longest axis of each plot. Every $12 \mathrm{~m}$ along the transect, we established one sampling point, mak- 
ing a total of 6 sampling points per plot ( 3 per transect). Soil samples were collected every season from July 1999 to January 2002.

The two montane forests in Chiloé National Park (Table I) were studied from 1994 to 1996. Sampling and analytical methods are described in Pérez et al. (1998).

FIELD SAMPLING AND LABORATORY ANALYSIS

\section{Non-symbiotic $\mathrm{N}$ fixation}

The acetylene reduction technique (Myrold et al. 1999) was used to estimate non-symbiotic N fixation rates for different soil compartments: fine litter $\left(\mathrm{O}_{l}\right.$ horizon), coarse woody debris (> 5 $\mathrm{cm}$ diameter) and mineral soil. This method is based on the ability of nitrogenase to reduce acetylene to ethylene. Six sample points in each permanent plots were used for field incubations of litter and mineral soil. Each season from August 2000 until January 2002, litter samples were collected in an area adjacent to each sample point and placed inside one-liter gastight glass jars. Additionally, during spring and summer 2000 and 2001, ca. 70-300 g of coarse woody debris of different decay classes were collected from the forest floor and incubated in the field using the same methodology.

Additionally, in lowland North Patagonian forest we incubated intact soil cores of surface mineral soil in the field, during August 2001, November 2001 and January 2002. These samples were incubated in a mixture of air and acetylene at $10 \% \mathrm{v} / \mathrm{v}$ for up to 2 days. An additional sample was incubated without acetylene as a control. One gas sample per jar was taken every day and injected in $3 \mathrm{ml}$ Venojets. In the laboratory gas samples were analyzed for ethylene production using a gas chromatograph equipped with a Porapack column and FID detector. Acetylene reduction activity was calculated from the slope of the lineal fit of the ethylene production during two days of incubation in one liter headspace. The stoichiometric conversion factor used to estimate the annual rate of non symbiotic $\mathrm{N}$ fixation was one third of ethylene reduction activity (Robertson et al. 1999). The rate of $\mathrm{N}$ fixation was then multiplied by the biomass of each soil compartment at each study site to obtain ecosystem.

\section{In situ net $\mathrm{N}$ mineralization rates}

At each sample point, soil samples (ca. $300 \mathrm{~g}$ ) from the surface horizon $\left(\mathrm{A}_{h}\right.$ horizon, 0-10 $\mathrm{cm}$ ) were sieved in the field. The sample was divided in two. One subsample was taken to the laboratory to determine the initial content of ammonium and nitrate in the soil solution. The second subsample was deposited inside a polyethylene zip lock bag and returned to the soil (Eno 1960). After 30-35 days of field incubation, samples were retrieved and taken to the laboratory to determine the final contents of ammonium and nitrate. Soil extractions were carried out in a $1 \% \mathrm{KAl}\left(\mathrm{SO}_{4}\right)_{2}$ solution (1:4), and mineral $\mathrm{N}$ was estimated by fractionated steam distillation (Pérez et al. 1998).

The total amount of available $\mathrm{N}$ is the sum of ammonium plus nitrate. The monthly rate of nitrogen production was estimated as the difference between the initial and final amounts of nitrate and ammonium produced during incubation, standardized for one month. We estimated a seasonal rate as the product of the monthly rate multiplied by three. The annual rate of net $\mathrm{N}$ mineralization in the first $10 \mathrm{~cm}$ of soil was estimated as the sum of the four seasonal rates, expressed on an hectare basis.

\section{Denitrification}

Denitrification rates were determined with the acetylene inhibition essay in intact soil cores (Groffman et al. 1999). Eight soil cores per forest were taken each season from July 2001 to July 2002. Data reported here represent the average value $(\mathrm{N}=4)$ for the four seasons. Samples were taken with a $100 \mathrm{~cm}^{3}$ steel cylinder and stored for up to 16 hours before the incubation in the laboratory. Soil samples were placed inside $500 \mathrm{ml}$ gastight glass jars and incubated 6 hours under a 10\% v/v acetylene atmosphere. Gas samples were taken after 0,2 and 6 hours of incubation and stored in evacuated Venojets. Samples were frozen until analyzed. $\mathrm{N}_{2} \mathrm{O}$ concentration in the gas samples was determined using a gas chromatograph equipped with a Porapack Q column 80/100 mesh and an ECD. Denitrification rates were estimated from $\mathrm{N}_{2} \mathrm{O}$ concentration increases between time 0 and 6 hours.

Data for Chilean forests in this study were compared with the available data on $\mathrm{N}$ fluxes reported for other temperate forests from both northern and southern hemispheres. The comparison 
of in situ net $\mathrm{N}$ mineralization with northern temperate forests considered only old-growth forests (both deciduous and evergreen). For non-symbiotic $\mathrm{N}$ fixation and denitrification we also included early successional forests in the comparisons. Soil types, climate and topography also varied among the temperate forests compared.

\section{RESULTS}

\section{Non SyMbiotic N-FIXATION}

Average rates documented on the forest floor of northern temperate forests (Fig. 2) are nearly $1 \mathrm{~kg}$ ha $^{-1}$ year $^{-1}$ (Perry 1994). Old-growth southern temperate forests in Chiloé present variable rates in the litter layer (Fig. 2), depending on forest type (0.23$2.26 \mathrm{~kg} \mathrm{~N} \mathrm{ha}^{-1}$ year $^{-1}$ ). Woody debris in the Nothofagus-Podocarpus mixed forest presented higher rates of $\mathrm{N}$-fixation than mineral soil, which had negligible values (1.31 and $0.03 \mathrm{~kg} \mathrm{~N} \mathrm{ha}^{-1}$ year $^{-1}$, respectively, Fig. 3). The sum of average $\mathrm{N}$ fixation rates in the litter layer and coarse woody debris yields higher values than the average rates reported for the forest floor in northern temperate forest ecosystems. An old-growth forest in New Zealand had the highest rates among southern hemisphere forests (Dawson 1983). However, the maximum rates of $\mathrm{N}$-fixation have been recorded in the mineral soil of temperate deciduous forests of eastern North America (ca. $8 \mathrm{~kg} \mathrm{~N} \mathrm{ha}^{-1}$ year $^{-1}$ ), either old-growth or second-growth (Dawson 1983, Jones \& Bangs 1985). In a native Eucalyptus forest in Australia, moderate rates were measured in the litter layer and soil (Baker \& Attiwill 1984). The litter layer of young Pseudotsuga menziessi Mirb. forests in Oregon showed maximum values of ca. $1 \mathrm{~kg} \mathrm{~N} /$ ha year (Heath et al. 1988). Coarse woody debris also made important contributions to $\mathrm{N}$ fixation in eastern and central US forests (Roskoski 1980, Jurgensen et al. 1987).

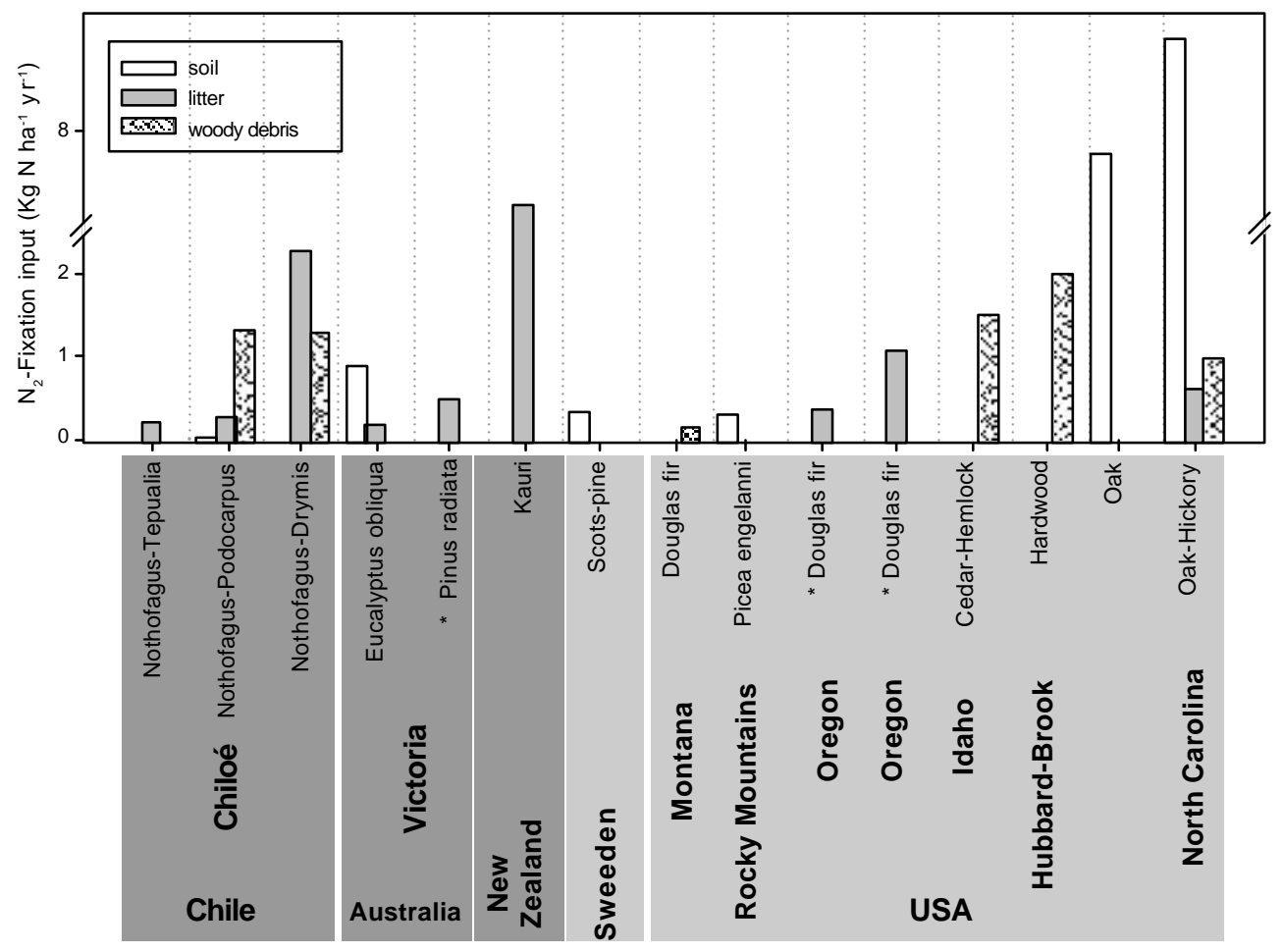

FIgURE 2. Annual non-symbiotic N fixation rates in southern (darker panel) and northern hemisphere temperate forests (lighter panel), estimated for three soil compartments: surface mineral soil, litter and coarse woody debris. In some cases data were not available for a given soil compartment. Asterisks indicate successional or plantations forests, all others are old-growth stands. References are: Roskoski 1980, Dawson 1983, Baker \& Attiwill 1984, Jones \& Bangs 1985, Heath et al. 1988 , Jurgensen et al. 1987. 


\section{NET N MINERALIZATION}

Old-growth, evergreen forests of Chiloé Island presented low to intermediate rates of in situ net $\mathrm{N}$ mineralization (12-30 kg N ha ${ }^{-1}$ year-1 ${ }^{-1}$ Fig. 3). Considering all temperate forests, the highest values have been reported for conifer and deciduous forests in eastern and central US and Canadá ( $c a .100$ $\mathrm{kg} \mathrm{ha}^{-1}$ year $^{-1}$, Nadelhofer et al. 1982, Mladenoff 1987, Strader et al. 1989). In conifer and deciduous forests of central US, Reich et al. (1997) have reported rates of net $\mathrm{N}$ mineralization as high as
$130 \mathrm{~kg} \mathrm{~N} \mathrm{ha}^{-1}$ year-1 $^{-1}$ However, intermediate values (30-80 $\mathrm{kg} \mathrm{N} \mathrm{ha}^{-1}$ year-1) $^{-1}$ are also reported for conifer and deciduous forests in these regions (Nadelhofer 1982, Pastor et al. 1984, Mladenoff 1987, Hill \& Schackleton 1989, Friedland et al. 1991, Plymale et al. 1987, Aber et al. 1993). Lower rates of net $\mathrm{N}$ mineralization in North America (Fig. 3) are reported for forests of the Pacific Northwest (6-16 kg ha-1 year ${ }^{-1}$, Myrold et al. 1989, Hart \& Firestone 1989), which have lower pollution-loads than eastern US forests.

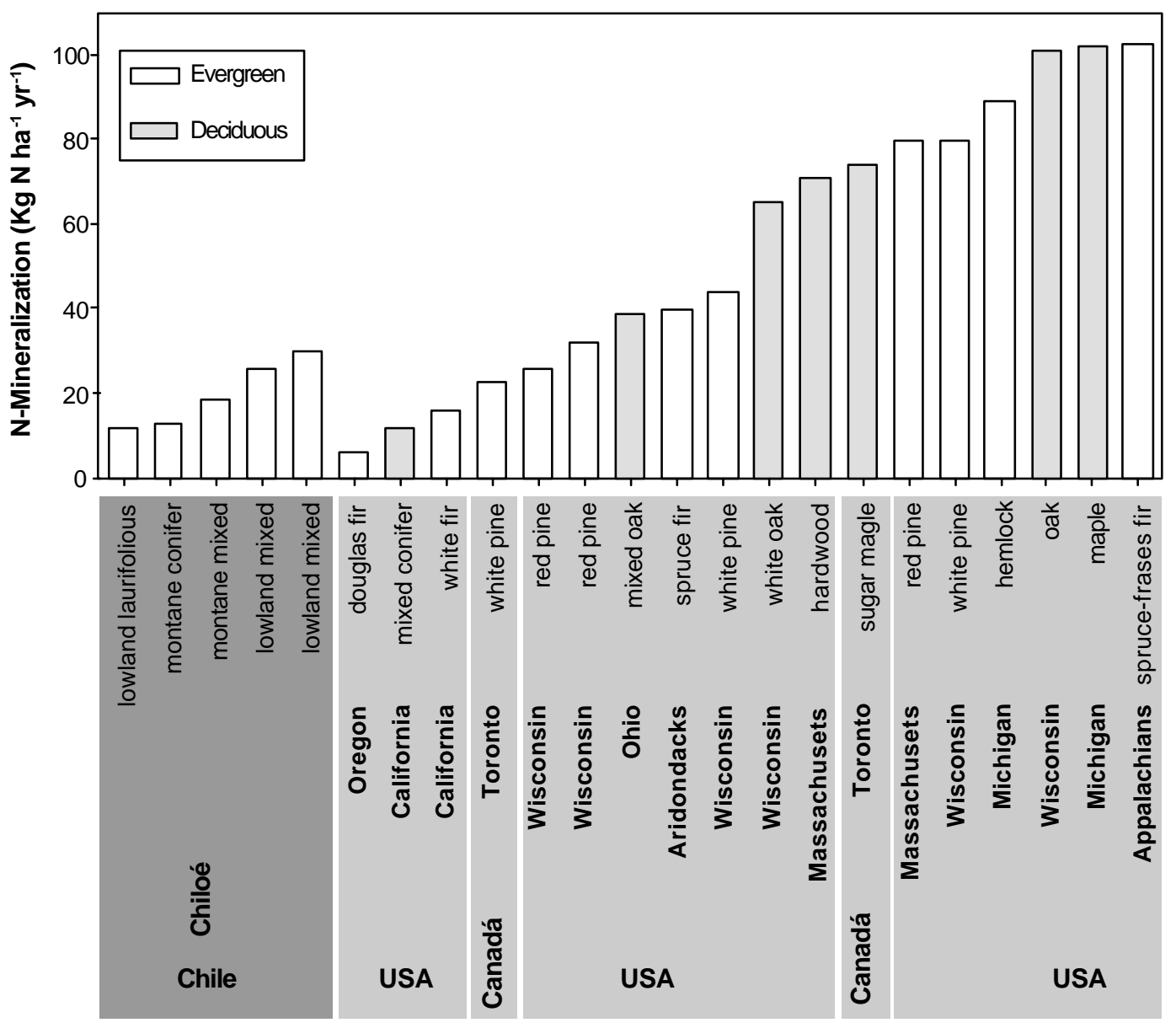

FIgURE 3. Annual net nitrogen mineralization rates in soils of southern Chilean (darker panel) and North American (lighter panel) temperate forests. Data are shown separately for evergreen and deciduous forests. References are: Nadelhofer et al. 1982, Pastor et al. 1984, Mladenoff 1987, Plymale et al. 1987, Strader et al. 1989, Myrold et al. 1989, Hill \& Schackleton 1989, Hart \& Firestone 1989, Friedland et al. 1991, Aber et al. 1993. 


\section{Denitrification}

Both a successional and an old-growth forest stand on Chiloé Island (Fig. 4) presented lower rates of denitrification (26-47 $\left.\mu \mathrm{g} \mathrm{N} \mathrm{m}^{2} \mathrm{day}^{-1}\right)$ than temperate forests located in heavily industrialized regions of North America and especially Europe, such as Germany and Austria (70-1300 $\mu \mathrm{g}$ $\mathrm{N} \mathrm{m}^{2}$ day $^{-1}$ : Robertson et al. 1987, Zak \& Grigal
1991, Butterbach et al. 1997, Henrich \& Haselwandter 1997). Based on our data, annual denitrification rates for Chiloé Island forests are estimated in $c a .0 .2 \mathrm{~kg} \mathrm{~N} / \mathrm{ha}$, which is two orders of magnitude lower than the estimated rate of 20 $\mathrm{kg} \mathrm{N} / \mathrm{ha} /$ year for a forest located in areas of the Netherlands subjected to high industrial air pollution (Tietama et al. 1991).

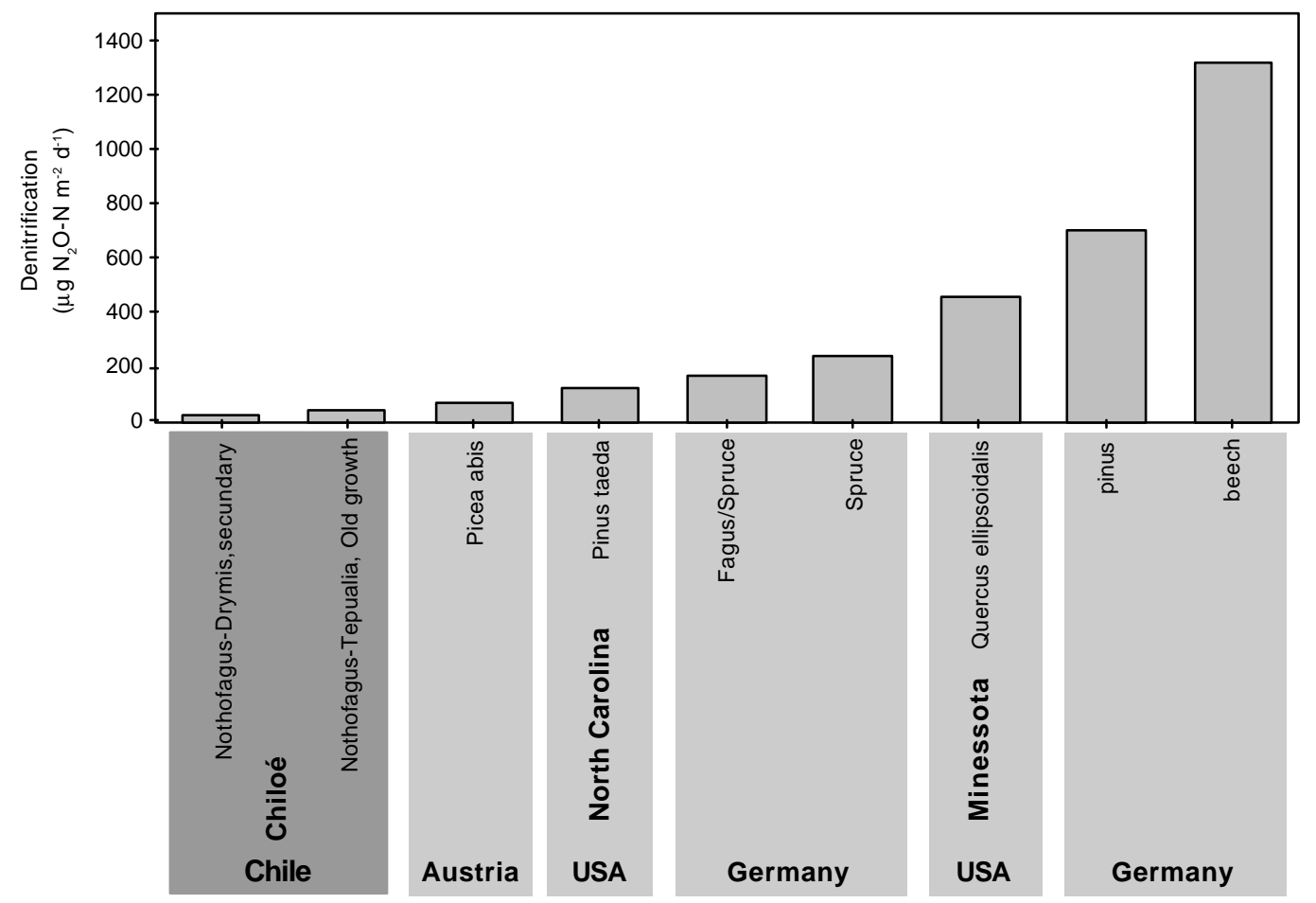

FIgure 4. Denitrification rates in soils of southern Chilean (darker panel) and northern hemisphere (lighter panel) temperate forests. References are: Robertson et al. 1987, Zak \& Grigal 1991, Tietama et al. 1991, Butterbach et al. 1997, Henrich \& Haselwandter 1997.

\section{CONCLUSIONS}

1) A major proportion of non-symbiotic $\mathrm{N}$ fixation in Chilean temperate, evergreen forests occurs in the litter layer (Fig. 2), in contrast to northern hemisphere, temperate deciduous forests, where this process is largely restricted to the mineral soil in a deeper soil horizon. In the mineral soil, however, the risks for $\mathrm{N}$ losses due to hydrologic leakage are higher. This suggests that a more "leaky" $\mathrm{N}$ cycle operates in northern hemisphere temperate forests.
2) In temperate forests of the world, the highest rates of net $\mathrm{N}$ mineralization have been measured in eastern and central US forests (Fig. 3), indicating that chronic $\mathrm{N}$ deposition due to industrial air pollution enhances SOM mineralization in forest soils. Markedly lower rates of $\mathrm{N}$ mineralization recorded in Chiloé forests (Fig. 3) may indicate a relatively tighter internal $\mathrm{N}$ cycle in unpolluted forests, because the smaller amounts of inorganic $\mathrm{N}$ produced per unit time may be rapidly taken up by plants and microorganisms, with minimum losses to downstream ecosystems. 
Gayana Bot. 60(1), 2003

3) Very low rates of denitrification were found in southern temperate forests, even in the poorly drained Tepualia forest (Fig. 4) where denitrification could be favored by abiotic conditions. This is the first time that denitrification rates have been reported for Chilean forest soils. Values for the two Chilean forests studied are remarkably low compared to the rates reported for welldrained northern temperate forests located in high $\mathrm{N}$ deposition areas of Europe and North America. This again supports the idea of a tighter internal $\mathrm{N}$ cycle in Chiloé forests, as gaseous $\mathrm{N}$ losses by denitrification are minimal.

\section{ACKNOWLEDGMENTS}

Funding was provided by Fondecyt 1990946, Millenium Nucleus P99-103FICM, IAI-CRN-012, Fundación Antorchas, and FONDAP-FONDECYT 1501-0001 to the Center for Advanced Studies in Ecology \& Biodiversity. This is a contribution to the Research Program of "Senda Darwin" Biological Station, Chiloé, Chile.

\section{REFERENCES}

Aber, J.D., A. Magill, R. Boone, J.M. Melillo, P. Steudler, R. Bowden. 1993. Plant and soil reponses to chronic $\mathrm{N}$ additions at the Harvard Forest, Massachusetts. Ecological Applications 3: 156-166.

Aravena J.C., M.R. Carmona, C.A Pérez \& J.J. Armesto. 2002. Changes in tree species richness, stand structure and soil properties in a successional chronosequence in northern Chiloé Island, Chile. Revista Chilena de Historia Natural 75: 339360.

Armesto J.J., J.C. Aravena, C. Villagrán, C. A. Pérez \& G. G. Parker. 1995. Bosques templados de la Cordillera de la Costa. In: Ecología de los Bosques Nativos de Chile (eds. J.J. Armesto, C. Villagrán \& M. Kalin), pp. 199-212. Editorial Universitaria, Santiago.

BAKer, T.G. \& P.M. Attiwill.1984. Acetylene reduction in soil and litter from pine and eucalyptus forests in south-eastern Australia. Soil Biology and Biochemistry 16: 241-245.

Bormann, F.H. \& G.E. Likens 1979. Pattern and process in a forested ecosystem. Springer-Verlag, New York, USA. 253 pp.

Butterbach-Bahl, K., R. Gashe, L. Breuer \& H. Papen. 1997. Fluxes of $\mathrm{NO}$ and $\mathrm{N}_{2} \mathrm{O}$ from temperate forest soils: impact of liming on the $\mathrm{NO}$ and $\mathrm{N}_{2} \mathrm{O}$ emissions. Nutrient Cycling in Agroecosystems 48:79-90.

Dawson, J.O. 1983. Dinitrogen fixation in forest ecosystems. Canadian Journal of Microbiology 29: 979-992.

ENo, C.F. 1960. Nitrate production in the field by incubating the soil in polyethylene bags. Soil Science Society of America Proceedings 24: 277299.

Friedland, A.J., E.K. Miller, J.J. Battles \& J.F. Thorne. 1991. Nitrogen deposition, distribution and cycling in a subalpine spruce-fir forest in the Adirondacks, New York, USA. Biogeochemistry 14: 31-55.

Groffman, P.M., E.A. Holland, D.D. Myrold, G.P. Robertson \& X. Zou. 1999. Denitrification. In: Standard Soil Methods for Long Term Ecological Research. (eds. Robertson, G.P., D.C. Coleman, C.S. Bledsoe \& P. Sollins). pp. 241-257. Oxford University Press, New York.

Hart, S.C. \& M.K. Firestone. 1989. Evaluation of three in situ soil nitrogen availability assays. Canadian Journal of Forest Research 19: 185-191.

Heath, B., P. Sollins, D.A. Perry \& K. Cromack. 1988. Asymbiotic nitrogen fixation in litter from Pacific Northwest. Canadian Journal of Forest Research 18: $68-74$

Hedin L.O., J. J. Armesto \& A. H. Johnson. 1995. Patterns of nutrient loss from unpolluted old-growth temperate forests: evaluation of biogeochemical theory. Ecology 76: 493-509.

Henrich, M. \& K. Haselwandter,.1997. Denitrification and gaseous nitrogen losses from an acid spruce forest soil. Soil Biology and Biochemistry 29:1529-1537.

Hill, A.R. \& M. Schackleton. 1989. Soil N mineralization and nitrification in relation to nitrogen solution chemistry in a small forested watershed. Biogeochemistry 8: 167-184.

Johnson, D.W. 1992. Nitrogen retention in forest soils. Journal of Environmental Quality 21: 1-12.

Jones, K \& D. Bangs. 1985. Nitrogen fixation by free living heterotrophic bacteria in an oak forest: The effect of liming. Soil Biology and Biochemistry 17: 705-709.

Jurgensen, M.F., M.J. Larsen, R.T. Graham \& A.E. HARVEY. 1987. Nitrogen fixation in woody residue of northern Rocky Mountain conifer forests. Canadian Journal of Forest Research 17: 12831288.

Mladenoff, D.J. 1987. Dynamics of nitrogen mineralization and nitrification in hemlock and hardwood tree fall gaps. Ecology 68: 1171-1180.

Myrold, D. D., P.A. Matson, D.L. Peterson. 1989. Relationship between soil microbial properties and aboveground stand characteristics of conifer forests in Oregon. Biogeochemistry 8: 265-281.

Myrold,D.D., R.R. RuEss \& M.J. KLUG. 1999. Dinitrogen fixation. In: Standard Soil Methods for Long Term Ecological Research (eds. Robertson, G.P., 
D.C. Coleman, C.S. Bledsoe \& P. Sollins). pp. 241-257. Oxford University Press, New York.

Nadelhoffer, K.J., J. Aber \& J.M. Melillo. 1982. Leaf litter production and soil organic matter dynamics along a nitrogen availability gradient in southern Wisconsin (USA). Canadian Journal of Forest Research 13: 12-21.

Pastor, J., J.D. Aber, C.A. \& Mc Claugherty. 1984. Aboveground production and $\mathrm{N}$ and $\mathrm{P}$ cycling along a nitrogen mineralization gradient on Blackhawk Island, Wisconsin. Ecology 65: 256268.

Perakis, S.S. \& L.O. Hedin 2002. Nitrogen loss from unpolluted South American forests mainly via dissolved organic compounds. Nature 415: 416419.

Pérez C. A., L. O Hedin \& J.J. Armesto.1998. Nitrogen mineralization in two unpolluted old-growth forests of contrasting biodiversity and dynamics. Ecosystems 1: 361-373.

Perry, D.A. 1994. Forest Ecosystems. The Johns Hopkins University Press, Maryland. 649 pp.

Plymale, A.E., R.E. Boerner \& T.J. Logan. 1987. Relative nitrogen mineralization and nitrification in soils of two contrasting hardwood forests: effect of site microclimate and initial soil chemistry. Forest Ecology and Management 21: 21-36.

Reich, P.B., D. F. Grigal, J.D. Aber, \& S.T. Gower. 1997. Nitrogen mineralization and productivity in 50 hardwood and conifer stands on diverse soils. Ecology 78: 335-347.

Robertson,P., P. Vitousek,P. Matson \& J.M Tiedje. 1987. Denitrification in a clearcut Loblolly pine (Pinus taeda L.) plantation in the southeastern US. Plant and Soil 97: 119-129.

Roskoski, J. 1980. Dinitrogen fixation in hardwood forests on northeastern United States. Plant and Soil 54: 33-44.

Strader, R.H., D. Binkley \& C.G. Wells. 1989. Nitrogen mineralization in high elevation forests of the Appalachians. I. Regional patterns in southern spruce-fir forests. Biogeochemistry 7: 131-145.

Tietama, A., W. Bouten \& P.E. Wartenbergh. 1991. Nitrous oxide dynamics in an oak-beech forest ecosystem in the Netherlands. Forest Ecology and Management 44: 53-61.

Vitousek, P.M, J. Aber, R.W. Howarth, G.E.Likens, P.A Matson, D.W. Schindler, W.H. Schlesinger \& G.D. Tilman. 1997. Human alteration of the global $\mathrm{N}$ cycle: Causes and consequences. Issues in Ecology 1:1-6.

Weathers, K.C., G.M. Lovett., G.E. Likens \& N.F.M. CARACO. 2000. Cloudwater inputs of nitrogen to forest ecosystems in southern Chile: Form, fluxes, and sources. Ecosystems 3: 590-595.

Wilson, M. F. \& J. J. ARmesto. 1996. The natural history of Chiloé: on Darwin's trail. Revista Chilena de Historia Natural 69: 149-161.

ZAK, D.R. \& D.F. GRIGAL. 1991. Nitrogen mineralization, nitrification and denitrification in upland and wetland ecosystems. Oecologia 88: 89-196.

Zuberer D.A. 1998. Biological dinitrogen fixation: introduction and nonsymbiotic. In: Principles and applications of soil microbiology (eds. D.M. Sylvia, J.J. Fuhrmann, P.G. Hartel \& D.A. Zuberer), pp. 295-321. Prentice Hall, New Jersey, USA. 